\title{
Article
}

|||||||||||||||||||||||||||||||| $\mid$

\section{Assessment of Inhomogeneity of Exposure to Radiation Workers in Homogeneous Exposure Situations in Nuclear Industry and Accelerator Facility by Using Monte Carlo Calculations Coupled with a Mathematical Phantom -Exposure to the Lens of the Eye in Homogeneous Exposure Situation Due to Gamma and Beta Rays-}

\author{
Munehiko KowatarI $^{\dagger}$ and Hiroshi YoshitomI \\ Department of Radiation Protection, Nuclear Science Research Institute, Japan Atomic Energy Agency \\ 2-4 Shirakata, Tokai-mura, Naka-gun, Ibaraki 319-1195, Japan \\ ${ }^{\dagger}$ kowatari.munehiko@jaea.go.jp \\ Received February 12, 2019 \\ Accepted April 15, 2019
}

\begin{abstract}
The recommended annual limit of equivalent dose to the lens of the eye has decreased to $20 \mathrm{mSv} y^{-1}$ from the current limit of $150 \mathrm{mSv} y^{-1}$. In terms of occupational exposure to radiation workers, exposure inhomogeneity plays an important role when estimating equivalent dose to the eye lens from readings of dosimeters worn by workers on their trunk. The authors focused on homogeneous exposure situations that radiation workers may encounter in nuclear and accelerator facilities. Moreover, the authors investigated how radiation workers are exposed non-homogenously in homogeneous exposure scenarios, where radiation workers may usually be encountered, regardless of their radiation works. In our previous study, we proposed a methodology to quantitatively evaluate the inhomogeneity of exposure. The homogeneity of exposure was evaluated by performing Monte Carlo calculations with a mathematical phantom under the isotropic and rotational irradiation geometries due to gamma and beta rays. $H_{p}(3)_{\text {eye }} / H_{p}(10)_{\text {trunk }}$ exceeded 1.0 even in the case of homogenous exposure to gamma rays. Even in the homogeneous exposure scenarios, the $H_{p}(3)_{\text {eye }}$ might exceed the revised annual dose limit for radiation workers who are exposed close to annual dose limit. For exposure due to beta rays from ${ }^{90} Y$, the equivalent dose of the lens of the eye might overestimate around four times when estimated from the $H_{p}(0.07)$ measured on worker's trunk.
\end{abstract}

Key Words: eye lens dose, $H_{\mathrm{p}}(3)$, occupational exposure, radiation protection, Monte Carlo calculation

\section{Introduction}

Based on recent findings pertaining to radiation cataract, the International Commission on Radiological Protection (ICRP) recommended that the annual equivalent dose limit to the lens of the eye be reduced to $20 \mathrm{mSv}$ averaged over five consecutive years and $50 \mathrm{mSv}$ in a single year from $150 \mathrm{mSv}$ for occupational exposure in planned situation. ${ }^{1)}$ An effective dose limit for radiation workers, that is $20 \mathrm{mSv}$ per year averaged over five consecutive years and $50 \mathrm{mSv}$ in any single year, has been already established and is being retained. In response, a comprehensive study, called the Optimization of Radiation protection for Medical staff (ORAMED) project, ${ }^{2)}$ was conducted in the medical industry. 
Cases of occupational exposure to the lens of the eye in Japan have been studied as well. ${ }^{3)}$ However, a comprehensive study on eye lens dosimetry has yet to be conducted in the nuclear industry.

The authors investigate how radiation workers are exposed non-homogenously in homogeneous exposure scenarios in which radiation workers may usually be present, regardless of their task. This study aims to examine whether eye lens doses estimated from the data recorded at the trunk are under- or overestimated in homogenous exposure situations, by performing Monte Carlo (MC) calculations. The magnitude by which eye lens dose to radiation workers differs from whole-body dose in homogenous exposure scenarios has not been determined thus far, because the issue has not attracted adequate attention given by their relatively low dose received and the present annual eye lens dose limit $\left(150 \mathrm{mSv}^{-1}\right)$ in Japan (as of December 2018). More than $80 \%$ of radiation workers are designated "no significant exposure" in Japan. The difference in annual dose limit between eye lens and whole-body dose could allow discrepancy between doses actually received and those estimated from the data recorded by dosimeters worn radiation workers' trunk.

According to the current Japanese regulation on radiation protection, the equivalent dose to the lens of the eye of a radiation worker shall be estimated from personal dose equivalents, $H_{\mathrm{p}}(10)$ and/or $H_{\mathrm{p}}(0.07)$, measured at the radiation worker's trunk. The larger value of the two measured personal dose equivalents is selected as the estimate of the equivalent dose to the lens of the eye. This method can over- or underestimate the equivalent dose to the lens of the eye because of reasons such as inhomogeneity of exposure, and unsuitable personal dose equivalent to be monitored. However, the method will work properly so long as the annual equivalent dose limit is maintained at $150 \mathrm{mSv}$.

Attention must be paid to the method of estima- tion of equivalent dose to the eye lens from the $H_{\mathrm{p}}(10)$ or $H_{\mathrm{p}}(0.07)$ values observed on workers' trunks. This is because implementation of the conventional methodology might easily violate the revised annual equivalent dose limit $\left(20 \mathrm{mSv}^{-1}\right)$ because of their lower equivalent dose limit and the methodology itself. Although additional dosimeters are worn on the collar or the forehead of radiation workers who are exposed non-homogenously, no additional dosimeters are worn by radiation workers engaged in normal operations, in which workers are thought to be exposed homogeneously to radiation over their entire bodies. Systematic investigation of the relationship between eye lens dose and personal dose equivalent measured on the trunk is required for exposure scenarios that radiation workers might encounter in the nuclear industry and in research accelerator facilities. The International Atomic Energy Agency (IAEA) TECDOC 17314) considers homogeneity of exposure a key factor.

In our previous study, ${ }^{5}$ we proposed a methodology to evaluate the homogeneity of exposure quantitatively before radiation work by using a proposed index defined as the ratio of personal dose equivalent of the lens of the eye to that of the whole body (or trunk) of a radiation worker, which was termed the homogeneity index (HI). HIs were estimated by performing MC calculations, and the calculation results were verified by phantom experiments in well-defined radiation calibration fields. Standard irradiation geometries, the isotropic (ISO) and rotational (ROT) specified in the ICRP Publication 74, ${ }^{\text {() }}$ were considered as typical examples of "homogenous exposure." As for the type of radiation, gamma and beta rays were selected for estimating the ratio of eye lens dose to trunk dose in homogenous exposure scenarios. 


\section{Materials and Methods}

$2 \cdot 1$ Homogenous index, $\mathrm{HI}$ and the MC calculation

The ratios of eye lens dose to the dose obtained at the trunk of radiation workers in homogenous exposure scenarios were estimated by means of $\mathrm{MC}$ calculations, to appropriately evaluate equivalent dose of the lens of the eyes of workers from readings obtained by dosimeters worn their trunks. To evaluate the homogeneity of radiation workers' exposure quantitatively, a HI was introduced in our previous study $^{5)}$ for eye lens monitoring, which was used in this study as well to perform quantitative analysis of homogeneity of exposure. The HIs were determined using the following equations:

$$
\begin{gathered}
\mathrm{HI}_{\text {eye }}(10)=H_{\mathrm{p}}(3)_{\text {head }} / H_{\mathrm{p}}(10)_{\text {trunk }} \\
\mathrm{HI}_{\text {eye }}(3)=H_{\mathrm{p}}(3)_{\text {head }} / H_{\mathrm{p}}(3)_{\text {trunk }} \\
\mathrm{HI}_{\text {eye }}(0.07)=H_{\mathrm{p}}(3)_{\text {head }} / H_{\mathrm{p}}(0.07)_{\text {trunk }}
\end{gathered}
$$

where $H_{\mathrm{p}}(\mathrm{d})$ is the personal dose equivalent at a depth of $\mathrm{d} \mathrm{mm}(\mathrm{d}=10,3$, or 0.07$)$ below a specified point of the body as denoted by the suffix. The subscripts head and trunk correspond to eye lens and whole-body monitoring, respectively. In this study, we focused on eye lens dose monitoring. For this purpose, $H_{\mathrm{p}}(3)$ is an appropriate quantity for personal monitoring. $\left.{ }^{4}\right)$ The calculated values of $H_{\mathrm{p}}(3)_{\text {head }}$ are directly adopted as the equivalent dose to the lens of the eyes, which is not measurable directly. The discrepancy between $H_{\mathrm{p}}(3)_{\text {head }}$ and the eye lens dose was not discussed, because almost identical absorbed doses were estimated at the head of workers and the lens of the eyes in a gamma-ray field, as described in our previous study. ${ }^{5)}$

The MC code PHITS 2.8.87) was employed for a series of calculations of $H_{\mathrm{p}}(\mathrm{d})_{\text {trunk }}$ and $H_{\mathrm{p}}(3)_{\text {head }}$. A mathematical phantom ${ }^{5}$ composed of the ICRU tissue was based on calculations of the conversion coefficients $^{8)}$ for personal dose equivalent to the lens of the eye for obtaining the HIs by using equations (1) to (3). In the calculations, absorbed doses were scored in a designated volume as described as follows. The scoring volumes of $H_{\mathrm{p}}(\mathrm{d})_{\text {trunk }}$ and $H_{\mathrm{p}}(3)_{\text {head }}$ were at a depth of $\mathrm{d} \mathrm{mm}$ below the left side of the chest $(1.0 \mathrm{~cm}$ in length $(\mathrm{L}) \times 6.18 \mathrm{~cm}$ in width $(\mathrm{W}) \times 0.01 \mathrm{~cm}$ in depth (D) for $\mathrm{d}=10$ and 3 , and $1.0 \mathrm{~cm}(\mathrm{~L}) \times 6.18 \mathrm{~cm}$ (W) $\times 0.005 \mathrm{~cm}$ (D) for $\mathrm{d}=0.07$ ), and at a depth of $3 \mathrm{~mm}$ below the forehead between the eyes $(1.0 \mathrm{~cm}$ $(\mathrm{L}) \times 3.69 \mathrm{~cm}(\mathrm{~W}) \times 0.01 \mathrm{~cm}(\mathrm{D}))$ corresponding to relevant personal monitoring and the definition of personal dose equivalent.

The isotropic (ISO) and rotational (ROT) irradiation geometries described in ICRP documents were employed to reproduce "homogenous exposure scenario" to radiation workers in the $\mathrm{MC}$ calculations. As for the ISO irradiation geometry, gamma and beta rays were considered the source of exposure, which radiation workers often encounter in the nuclear industry and in research accelerator facilities. With regard to homogenous exposure due to gamma rays, calculations were made for mono-energetic gamma rays of energies ranging from 0.06 to $6.0 \mathrm{MeV}$. As for beta-ray exposure, beta rays from ${ }^{41} \mathrm{Ar},{ }^{90} \mathrm{Y}$ and ${ }^{106} \mathrm{Rh}$ were considered, and the HIs were calculated for each beta ray source. In addition to the ISO irradiation geometry, the ratio of eye lens dose to wholebody dose obtained in case of the ROT irradiation geometry were assessed for ${ }^{137} \mathrm{Cs}$ and ${ }^{60} \mathrm{Co}$ gamma ray calculations and the benchmark measurement as described below.

\subsection{Benchmark experiments}

The calculated HIs was verified by comparing them with HIs measured in the benchmark measurements by using a simplified physical phantom, which is shown in Fig. 1.

Measurements were performed at the Facility of Radiation Standards in Japan Atomic Energy Agency (JAEA).9) The simplified physical phantom consists 

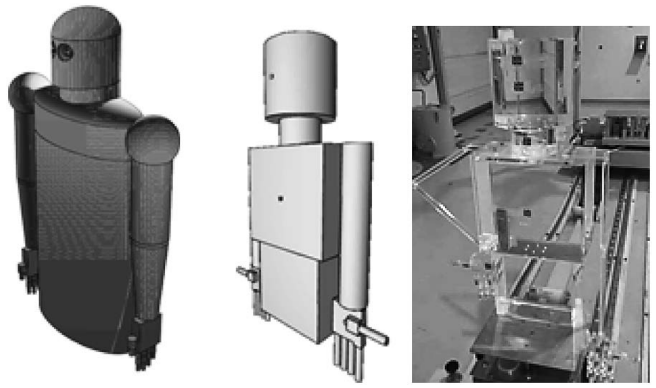

Fig. 1 Schematic view of the mathematical phantom (left) used for the calculations of the HIs and the physical phantom (center: the model for MC calculations, right: the picture of the phantom) for the benchmark.

of four PMMA-made water tanks and PMMA-made hands. As for the posture of the simplified physical phantom, the head angle and direction of trunk and abdomen were adjustable. The hands could be positioned freely as well. Optically-stimulated luminescence dosimeters (OSLD) (nanoDot ${ }^{\mathrm{TM}}$ manufactured by Landauer. Inc.) were employed to measure the dose at specified positions on the phantom. For the benchmark measurements, the anterior-posterior (AP) irradiation geometry was selected in ${ }^{60} \mathrm{Co}$ gamma rays and ${ }^{90} \mathrm{Sr}-{ }^{90} \mathrm{Y}$ beta rays. The HIs measured with the AP irradiation geometry agreed with calculated values within 3\%. Detail of the verification can be found in the literature, ${ }^{5)}$ and it was concluded that the proposed method is applicable to actual radiation workplaces. ${ }^{10)}$

\section{Results and Discussion}

\section{$3 \cdot 1$ Gamma ray irradiation}

The ratio of $H_{\mathrm{p}}(3)$ of the lens of the eye to $H_{\mathrm{p}}(10)$ on the trunk, that is, $\mathrm{HI}_{\text {eye }}(10)$ in the ISO irradiation geometry, was evaluate by performing MC calculations by introducing mono-energetic gamma rays with energies ranging from 0.06 to $6.0 \mathrm{MeV}$. Fig. 2 shows variations in $\mathrm{HI}_{\text {eye }}(10)$ with respect to incident gamma-ray energy.

As shown in Fig. 2, $\mathrm{HI}_{\text {eye }}(10)$ was estimated to be

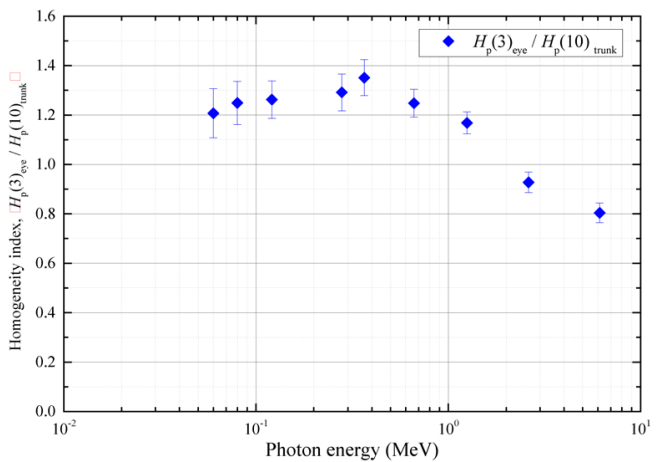

Fig. 2 Variation of ratio of $H_{\mathrm{p}}(3)$ of the lens of the eye to $H_{\mathrm{p}}(10)$ on trunk with respect to incident gamma ray energy. Calculate values were depicted in the figure. Mathematical phantom was used for calculation (Color online).

greater than 1.0 for incident gamma rays. This implies that the equivalent dose to the lens of the eyes of workers in the homogenous exposure scenario would be underestimated if the readings of $H_{\mathrm{p}}(10)$ from the dosimeters worn on workers' trunks were the best estimates of $H_{\mathrm{p}}(3)_{\text {eye }}$ of radiation workers. Particularly, the ratio $H_{\mathrm{p}}(3)_{\text {eye }} / H_{\mathrm{p}}(10)_{\text {trunk }}$ was estimated to be approximately 1.2 in ${ }^{137} \mathrm{Cs}(0.662 \mathrm{MeV})$ and ${ }^{60} \mathrm{Co}(1.25 \mathrm{MeV})$, which can be typically found in nuclear facilities.

As shown in Table 1, the ratios of conversion coefficient of the air-kerma to personal dose equivalent for ${ }^{137} \mathrm{Cs}$ and ${ }^{60} \mathrm{Co}$ gamma ray are calculated to be less than 1.0. Results obtained by MC calculations are not simply explained by the difference of the conversion coefficient used for evaluation of personal dose equivalent. Irradiation geometry, namely the relationship between the gamma ray source and the worker's trunk (or the lens of the eye) could affect the energy deposition due to exposure to gamma rays.

Calculated result implies that the estimated $H_{\mathrm{p}}(3)_{\text {eye }}$ values from readings of $H_{\mathrm{p}}(10)$ from dosimeter worn on worker's trunk would be around 0.83 $(=1 / 1.2)$ times the $H_{\mathrm{p}}(3)$ of the lens of the eyes that were actually exposed. Considering the radiation work which has been planned external exposure dose 
Sept. M. Kowatari and H. Yoshitomi : Assessment of Inhomogeneity of Exposure to Radiation Workers in Homogeneous Exposure Situations in Nuclear Industry and Accelerator Facility by Using Monte Carlo Calculations Coupled with a Mathematical Phantom

Table 1 Ratios of the conversion coefficient of air kerma to personal dose equivalent with respect to radiation quality. Values are taken from reference 11 to 13

\begin{tabular}{|c|c|c|c|c|c|c|}
\hline $\begin{array}{c}\text { Radiation } \\
\text { quality R }{ }^{11)}\end{array}$ & $\begin{array}{l}\text { mean } \\
\text { energy } \\
(\mathrm{keV})^{11)}\end{array}$ & $h_{\mathrm{pK}}\left(10,0^{\circ}\right)_{\text {trunk }}{ }^{*}$ & $h_{\mathrm{pK}}\left(3,0^{\circ}\right)_{\mathrm{cy} 1}{ }^{* *}$ & $h_{\mathrm{pK}}\left(3,0^{\circ}\right)_{\text {slab }}{ }^{* * *}$ & $\begin{array}{c}\text { cylinder / } \\
\text { trunk }\end{array}$ & $\begin{array}{l}\text { slab / } \\
\text { trunk }\end{array}$ \\
\hline $\mathrm{N}-60$ & 48 & 1.65 & 1.63 & 1.54 & 0.933 & 0.988 \\
\hline $\mathrm{N}-200$ & 164 & 1.57 & 1.53 & 1.42 & 0.904 & 0.975 \\
\hline $\mathrm{S}-\mathrm{Cs}$ & 662 & 1.21 & 1.22 & 1.18 & 0.975 & 1.01 \\
\hline $\mathrm{S}-\mathrm{Co}$ & 1250 & 1.15 & 1.16 & 1.10 & 0.957 & 0.957 \\
\hline $\mathrm{R}-\mathrm{F}$ & 6130 & 1.12 & 1.12 & 1.09 & 0.973 & 0.973 \\
\hline \multicolumn{7}{|c|}{ *: taken from the ISO 4037-3 } \\
\hline \multicolumn{7}{|c|}{$\begin{array}{l}\text { **: taken from Behrens (Radiation Protection Dosimetry (2012), Vol. 151, No. 3, pp. 450- } \\
455 \text { ) }\end{array}$} \\
\hline
\end{tabular}

379)

Table 2 Comparison of measured and calculated $\mathrm{HI}_{\text {eye }}(10)$ in the ROT irradiation geometry due to gamma ray. Results obtained in the ISO irradiation condition were also listed

\begin{tabular}{|c|c|c|c|}
\hline & ${ }^{241} \mathrm{Am}$ & ${ }^{137} \mathrm{Cs}$ & ${ }^{60} \mathrm{Co}$ \\
\hline $\begin{array}{c}\text { Gamma ray energy } \\
(\mathrm{MeV})\end{array}$ & 0.06 & 0.662 & 1.25 \\
\hline $\begin{array}{c}H_{\mathrm{p}}(3)_{\mathrm{eye}} \\
/ H_{\mathrm{p}}(10)_{\mathrm{trunk}} \\
\text { ROT irradiation } \\
\text { (experiments) }\end{array}$ & & $1.11 \pm 0.06$ & $1.03 \pm 0.06$ \\
\hline $\begin{array}{c}H_{\mathrm{p}}(3)_{\text {eye }} \\
/ H_{\mathrm{p}}(10)_{\mathrm{trunk}} \\
\text { ROT irradiation }\end{array}$ & $1.02 \pm 0.01$ & $1.22 \pm 0.01$ & $1.22 \pm 0.01$ \\
\hline $\begin{array}{c}H_{\mathrm{p}}(3)_{\mathrm{eye}} \\
/ H_{\mathrm{p}}(10)_{\mathrm{trunk}} \\
\text { ISO irradiation }\end{array}$ & $1.21 \pm 0.10$ & $1.25 \pm 0.06$ & $1.17 \pm 0.04$ \\
\hline
\end{tabular}

would reach the annual dose limit, which is $20 \mathrm{mSv}$ $\mathrm{y}^{-1}$, so additional monitoring for eye lens dose might be required for proper implementation of radiological protections.

The $\mathrm{HI}_{\text {eye }}(10)$ with the ISO irradiation geometry was estimated to be lower than 1.0 when the incident gamma ray energy exceeded $2 \mathrm{MeV}$. This result implies that the equivalent dose of the lens of the eyes of workers in homogenous exposure situation would be overestimated in that case. Although exposure due to gamma rays with less than $1 \mathrm{MeV}$ is predominant for radiation workers engaged in nuclear, workers exposed to gamma rays with an energy of $6 \mathrm{MeV}$ may be seen in maintenance of boiled water reactors (BWRs). ${ }^{14)}$ Exposure of radiation workers due to energetic X-rays by bremsstrahlung from electrons would occur in electron accelerator and X-ray accelerator facilities. In these cases, estimates of $H_{\mathrm{p}}(3)_{\text {eye }}$ from $H_{\mathrm{p}}(10)_{\text {trunk }}$ will be conservative. Consequently, special care might be required in the case of radiation workers who are to be exposed close to annual dose limit due to higher energy gamma rays $(>2 \mathrm{MeV}$ or more).

Rotational exposure is considered when determining external exposure in radiation works implemented in nuclear and accelerator facilities. Table 2 
compares the calculated $\mathrm{HI}_{\text {eye }}(10)$ between the ISO and the ROT irradiation geometries. For calculation of the ratios in case of the ROT irradiation geometry, mono-energetic gamma rays with energies of 0.06 , 0.662 and $1.25 \mathrm{MeV}$ were selected. Benchmark measurements using the simplified physical phantom were conducted with the ROT irradiation geometry by using the ${ }^{137} \mathrm{Cs}$ and ${ }^{60} \mathrm{Co}$ gamma-ray calibration fields.

No significant differences were seen in the case of each irradiation geometry for gamma rays with energies of 0.662 and $1.25 \mathrm{MeV}$, but a difference of approximately $20 \%$ was found between irradiation geometries for gamma rays with energy of $0.06 \mathrm{MeV}$. The calculated and measured $\mathrm{HI}_{\text {eye }}(10)$ in the ROT irradiation geometry differed for gamma rays with energies of 0.662 and $1.25 \mathrm{MeV}$. In terms of the results obtained in the ${ }^{137} \mathrm{Cs}$ gamma ray field, the calculated and measured $\mathrm{HI}_{\text {eye }}(10)$ agreed with each other, considering the uncertainties in both results. The discrepancy found in the results obtained in the ${ }^{60} \mathrm{Co}$ gamma ray field might be explained by differences in the experimental setup and calculation conditions using the mathematical phantom. In the benchmark measurement, the OSLDs set on the simplified physical phantom were used, since doses deposited onto the designate volume inside the math-

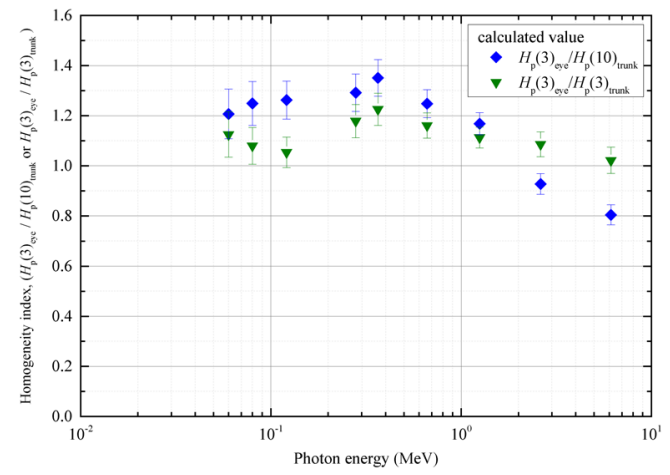

Fig. 3 Comparison of the ratio of $H_{\mathrm{p}}(3)_{\text {eye }} / H_{\mathrm{p}}(10)_{\text {trunk }}$ and $H_{\mathrm{p}}(3)_{\text {eye }} / H_{\mathrm{p}}(3)_{\text {trunk }}$ in the ISO irradiation geometry due to mono-energetic gamma rays (Color online). ematical phantom were calculated. The geometry of dose-accumulating volume for estimating the HIs were slightly different.

Fig. 3 shows a comparison of $\mathrm{HI}_{\text {eye }}(10)$ and $\mathrm{HI}_{\text {eye }}(3)$ in case of the ISO irradiation geometry due to mono-energetic gamma rays. As shown in the figure, $\mathrm{HI}_{\text {eye }}(10)$ was evaluated between 1.0 and 1.2 for gamma rays with energy ranging from 0.06 and $6.0 \mathrm{MeV}$. The equivalent dose to the lens of the eyes for radiation workers shall be estimated from personal dose equivalents, $H_{\mathrm{p}}(10)$ or $H_{\mathrm{p}}(0.07)$ measured on the workers' trunks in accordance with the regulation in Japan. The greater of the measured personal dose equivalents is selected as the estimate of the equivalent dose to the lens of the eyes. A better estimate of eye lens dose can be obtained if $H_{\mathrm{p}}(3)$ were to be monitored on radiation workers' trunks in addition to the current practice of measuring $H_{\mathrm{p}}(10)$ or $H_{\mathrm{p}}(0.07)$ on the trunk.

\section{$3 \cdot 2$ Beta ray irradiation}

As described above, the ratio of $H_{\mathrm{p}}(3)$ of the lens of the eye to personal dose equivalents on trunk in the ISO irradiation geometry were calculated by introducing beta rays from ${ }^{41} \mathrm{Ar},{ }^{90} \mathrm{Y}$ and ${ }^{106} \mathrm{Rh}$. Table 3 summarizes variations in ratio of $H_{\mathrm{p}}(3)$ of the lens of the eyes to the personal dose equivalent at each depth, namely $0.07,3$ and $10 \mathrm{~mm}$ on the trunk. The residual maximum energies for each beta-ray emitting radionuclide are listed on the table.

The calculations clearly indicate that the ratio of $H_{\mathrm{p}}(3)_{\text {eye }} / H_{\mathrm{p}}(\mathrm{d})_{\text {trunk }}$ depends strongly on beta-ray energy. For irradiation by ${ }^{90} \mathrm{Y}$, the ratio of $H_{\mathrm{p}}(3)_{\text {eye }} /$ $H_{\mathrm{p}}(\mathrm{d})_{\text {trunk }}$ reached approximately 200 . Estimating the eye lens dose to radiation workers from the readings of dosimeters worn on the trunk in terms of $H_{\mathrm{p}}(10)$ is inadequate in case of beta ray exposure.

Estimating the eye lens dose from the dosimeter readings in terms of $H_{\mathrm{p}}(0.07)$ would yield overestimates in the case of exposure due to beta rays. 
Sept. M. Kowatari and H. Yoshitomi : Assessment of Inhomogeneity of Exposure to Radiation Workers in Homogeneous Exposure Situations in Nuclear Industry and Accelerator Facility by Using Monte Carlo Calculations Coupled with a Mathematical Phantom

Table 3 Comparison of the ratio of $H_{\mathrm{p}}(3)_{\text {eye }}$ to personal dose equivalent in terms of $H_{\mathrm{p}}(0.07), H_{\mathrm{p}}(3)$ and $H_{\mathrm{p}}(10)$ on trunk in the ISO irradiation geometry due to beta ray

\begin{tabular}{cccc}
\hline Radio nuclide & ${ }^{41 \mathrm{Ar}}$ & ${ }^{90} \mathrm{Y}$ & $106 \mathrm{Rh}$ \\
\hline $\begin{array}{c}\text { Residual } \\
\text { maximum } \\
\text { energy }(\mathrm{MeV}) *\end{array}$ & 1.198 & 2.28 & 3.514 \\
\hline $\begin{array}{c}H_{\mathrm{p}}(3)_{\text {eye }} \\
/ H_{\mathrm{p}}(10)_{\text {trunk }}\end{array}$ & - & $(1.99 \pm$ & \\
\hline $\begin{array}{c}H_{\mathrm{p}}(3)_{\text {eye }} \\
/ H_{\mathrm{p}}(0.07)_{\text {trunk }}\end{array}$ & $(6.07 \pm 0.65) \times 10^{-3}$ & $0.237 \pm 0.003$ & $0.439 \pm 0.006$ \\
\hline $\begin{array}{c}H_{\mathrm{p}}(3)_{\text {eye }} \\
/ H_{\mathrm{p}}(3)_{\text {trunk }}\end{array}$ & $1.04 \pm 0.17$ & $1.06 \pm 0.02$ & $1.07 \pm 0.02$ \\
\hline Main component & & &
\end{tabular}

From the calculated results, the ratio of $H_{\mathrm{p}}(3)_{\text {eye }}$ ' $H_{\mathrm{p}}(0.07)_{\text {trunk }}$ ranges from 0.006 to 0.439 . For example, $H_{\mathrm{p}}(3)_{\text {eye }}$ in case of radiation workers exposed to a ${ }^{90} \mathrm{Sr}-{ }^{90} \mathrm{Y}$ beta ray would be overestimated by four times compared to the case in which the $H_{\mathrm{p}}(3)_{\text {eye }}$ for radiation workers were estimated from trunk dose in terms of $H_{\mathrm{p}}(0.07)$.

On the contrary, $H_{\mathrm{p}}(3)_{\text {trunk }}$ would yield better estimates of $H_{\mathrm{p}}(3)_{\text {eye }}$, regardless of the beta-ray energy. Independent to beta-ray energy, $H_{\mathrm{p}}(3)_{\text {eye }}$ for radiation workers exposed to beta rays can be estimated properly from the $H_{\mathrm{p}}(3)$ observed on radiation workers' trunks.

Based on results obtained in beta-ray fields, the authors proposed that individual monitoring of whole-body of radiation workers in terms of $H_{\mathrm{p}}(3)$ be provided when considering homogenous exposure to beta-ray. The IAEA TECDOC proposed that three primary impact factors should be considered in eye lens monitoring: (a) energy and angle of incident radiation, (b) geometry of the radiation field, and (c) personal protective equipment for doses due to neutrons, photons, and beta-rays, respectively. According to IAEA TECDOC, radiation protection officers should specify which type of radiations are involved and the additional eye lens monitoring required for beta-ray exposure, regardless of (a) their energy and (b) geometry of the radiation field. As summarized in Table $3, H_{\mathrm{p}}(3)_{\text {eye }}$ for workers in the homogenous exposure to beta-ray can possibly be monitored properly by dosimeters worn on workers' trunks in terms of $H_{\mathrm{p}}(3)$.

\section{Summary}

The authors evaluated the ratio of personal dose equivalent to the lens of the eyes to that of the wholebody in case of radiation workers under the homogenous exposure scenarios, which radiation workers can encounter in nuclear and accelerator facilities. A series of the MC calculations were perfomed by introducing a mathematical phantom to evaluate the ratio of $H_{\mathrm{p}}(3)_{\text {eye }} / H_{\mathrm{p}}(10)_{\text {trunk }}$. The irradiation geometries considered in the study were isotropic (ISO) and rotational (ROT). In addition to mono-energetic gamma rays with energies between $0.06 \mathrm{MeV}$ and $6.0 \mathrm{MeV}$, beta rays from ${ }^{41} \mathrm{Ar},{ }^{90} \mathrm{Y}$ and ${ }^{106} \mathrm{Rh}$ were considered in the calculations. Benchmark measurements performed using the simplified physical phantom made of PMMA were conducted with the ROT irradiation geometry using the ${ }^{137} \mathrm{Cs}$ and ${ }^{60} \mathrm{Co}$ gamma rays and ${ }^{90} \mathrm{Sr}-{ }^{90} \mathrm{Y}$ beta rays for verification of the calculation method.

The calculated $H_{\mathrm{p}}(3)_{\text {eye }} / H_{\mathrm{p}}(10)_{\text {trunk }}$ was between 0.8 to 1.4 with gamma ray energies ranging from 0.06 to $6.0 \mathrm{MeV}$ in the case of ISO irradiation geometry. The results were found to be within the criterion 
for individual monitoring (factor 1.5), as pointed out in the ICRP 75. The calculations explicitly showed that $H_{\mathrm{p}}(3)_{\text {eye }} / H_{\mathrm{p}}(\mathrm{d})_{\text {trunk }}$ depends strongly on energy of beta-ray. In the case of the irradiation by ${ }^{90} \mathrm{Y}, H_{\mathrm{p}}(3)_{\text {eye }} /$ $H_{\mathrm{p}}(10)_{\text {trunk }}$ reached approximately 200. Estimating the equivalent dose to eye lens of workers from the readings of dosimeters worn on trunk in terms of $H_{\mathrm{p}}(10)$ is inadequate in the case of beta-ray exposure. Estimating the eye lens dose using the readings by dosimeters in terms of $H_{\mathrm{p}}(0.07)$ yielded overestimates in the case of exposure to beta-ray. From the calculated results, $H_{\mathrm{p}}(3)_{\text {eye }} / H_{\mathrm{p}}(0.07)_{\text {trunk }}$ ranged from 0.006 to 0.439 . For example, $H_{\mathrm{p}}(3)_{\text {eye }}$ for radiation workers exposed in ${ }^{90} \mathrm{Sr}-{ }^{90} \mathrm{Y}$ beta-ray field would be overestimated by four times compared to the case in which $H_{\mathrm{p}}(3)_{\text {eye }}$ for radiation workers were estimated from their trunk doses in terms of $H_{\mathrm{p}}(0.07) . H_{\mathrm{p}}(3)_{\text {eye }} /$ $H_{\mathrm{p}}(3)_{\text {trunk }}$ was evaluated to be between 1.04 and 1.07, regardless of beta-ray energy. From the calculated results, $H_{\mathrm{p}}(3)_{\text {trunk }}$ would give a better estimate of $H_{\mathrm{p}}(3)_{\text {eye }}$ if radiation workers who are homogenously exposed to beta-rays were to be monitored in terms of $H_{\mathrm{p}}(3)$ on the trunks.

From a series of investigation of the ratio of personal dose equivalent to the lens of the eyes to that of the whole-bodies of radiation workers in the homogenous exposure scenarios, the following are implied and recommended;

1) $H_{\mathrm{p}}(3)_{\text {eye }} / H_{\mathrm{p}}(10)_{\text {trunk }}$ exceeded 1.0 in the case of homogenous exposure to gamma rays. Even in the case of homogeneous exposure to gamma rays, $H_{\mathrm{p}}(3)_{\text {eye }}$ might exceed the revised annual dose limit $\left(20 \mathrm{mSv}^{-1}\right)$ if it is estimated using the readings from dosimeters on the trunk of radiation workers exposed to levels to the annual dose limit.

2) Empirically, exposure to beta rays is considered "inhomogeneous exposure." In case of the ISO irradiation geometry, our findings show that $H_{\mathrm{p}}(3)_{\text {eye }} / H_{\mathrm{p}}(3)_{\text {trunk }}$ is between 1.04 and 1.07 , regardless of beta-ray energy. This implies that an almost identical dose equivalent to the lens of the eyes was estimated from the trunk dose. This was considered empirically "homogenous" with respect to worker exposure. These results challenge the empirical concept of homogeneous exposure.

3) $H_{\mathrm{p}}(3)_{\text {eye }} / H_{\mathrm{p}}(3)_{\text {trunk }}$ for gamma rays was found to be between 1.0 and 1.2 as well. Whole-body monitoring in terms of $H_{\mathrm{p}}(3)$ in addition to $H_{\mathrm{p}}(10)$ and $H_{\mathrm{p}}(0.07)$ would be preferable if $H_{\mathrm{p}}(3)_{\text {eye }}$ were to be estimated using the readings from dosimeters on their trunks of radiation workers.

\section{Funding}

This work was supported by the MHLW (Ministry of Health, Labor and Welfare, Japan) Hojokin Grant Number 150801-01.

\section{References}

1) International Commission on Radiation Protection, ICRP Statement on Tissue Reactions/Early and Late Effects of Radiation in Normal Tissues and OrgansThreshold Doses for Tissue Reactions in a Radiation Protection. ICRP Publication 118, Ann. ICRP, 41, (2012)

2) Vanhavere, F., et al., ORAMED: Optimization of radiation protection of medical staff. EURADOS Report 2012-02 (2012)

3) Akahane, K., Iimoto, T., Ichiji, T., Iwai, S., et al., Interim Report of the JHPS Expert Committee on Radiation Protection of the Lens of the Eye (V) -Current Occupational Radiation Exposure of the Lens of the Eye in Japan, Jpn., J. Health Phys., 50, 76-89 (2015), in Japanese

4) International Atomic Energy Agency, Implications for Occupational Radiation Protection of the New Dose Limit for the Lens of the Eye. IAEA TECDOC No. 1731, IAEA (2013)

5) Yoshitomi, H., et al., Assessment of equivalent dose of the lens of the eyes and the extremities to workers under nonhomogeneous exposure situation in nuclear and accelerator facilities by means of measurements 
Sept. M. Kowatari and H. Yoshitomi : Assessment of Inhomogeneity of Exposure to Radiation Workers in Homogeneous Exposure Situations in Nuclear Industry and Accelerator Facility by Using Monte Carlo Calculations Coupled with a Mathematical Phantom

using a phantom coupled with Monte Carlo simulation. IRPA-14 proceedings P06.67 (2016)

6) International Commission on Radiation Protection, Conversion Coefficients for use in Radiological Protection against External Radiation. ICRP Publication 74, Ann. ICRP, 26, (1996)

7) Sato, T., et al., Particle and Heavy Ion Transport Code System PHITS, Version 2.5.2, J. Nucl. Sci. Technol., 50, 913-923 (2013)

8) Behrens, R. and Dietze, G., Dose conversion coefficients for photon exposure of the human eye lens, Phys. Med. Biol., 56, 425-437 (2011)

9) Kowatari, M., et al., The Facility of Radiation Standards in Japan Atomic Energy Agency, present status and its research works on dosimetry. IRPA-14 Proceedings P06.72 (2016)

10) Yoshitomi, H., et al., Quantitative estimation of exposure inhomogeneity in terms of eye lens and extremity monitoring for radiation workers in the nuclear industry. Radiat. Prot. Dosim, (2018) doi: $10.1093 /$ rpd/ncy197
11) International Organization for Standardization, $X$ and gamma reference radiation for calibrating dosemeters and doserate meters and for determining their response as a function of photon energy-Part 3: Calibration of area and personal dosemeters and the measurement of their response as a function of energy and angle of incidence. ISO 4037-3. ISO (1999)

12) Behrens, R., Air kerma to $h p(3)$ conversion coefficients for a new cylinder phantom for photon reference radiation qualities, Radiat. Prot. Dosimetry, 151, 450-455 (2012)

13) Behrens, R., Air kerma to dose equivalent conversion coefficients not included in iso 4037-3, Radiat. Prot. Dosimetry, 147, 373-379 (2011)

14) United Nations Scientific Committee on the Effect of Atomic Radiation (UNSCEAR), Sources and effects of ionizing radiation, UNSCEAR 2008 report to the General Assembly with Scientific Annexes, Annex $\mathrm{B}$ exposures of the public and workers from various sources of radiation. United Nations (2010)

\title{
モンテカルロ計算を用いた原子力及び加速器施設における 均等被ばく状況下での放射線業務従事者の被ばくの不均一性に関する検討 $-\gamma$ 線及び $\beta$ 線による均等被ばく状況下での眼の水晶体への被ばく一
}

\author{
古渡意彦 ${ }^{\dagger}$, 吉富 寛 \\ 日本原子力研究開発機構原子力科学研究所放射線管理部 \\ 319-1195 茨城県那珂郡東海村大字白方 2-4 \\ ${ }^{\dagger}$ kowatari.munehiko@jaea.go.jp \\ 2019 年 2 月 12 日 受付 \\ 2019 年 4 月 15 日 受理
}

国際放射線防護委員会 (ICRP) 勧告では, 放射線業務従事者の眼の水晶体等価線量限度が現在 の限度である一年あたり $150 \mathrm{mSv}$ から 5 年平均で年間 $20 \mathrm{mSv}$ に大幅に引き下げられた。本稿では, 原子力及び加速器施設で放射線業務従事者が通常受ける, 均等被ばく状況に着目し, 従事者の水 晶体線量の体幹部で測定される線量との違いについて評価した。その結果, $\beta$ 線の場合, 体幹部で の $70 \mu \mathrm{m}$ 線量当量の測定值から推定する場合, 眼の水晶体等価線量を 4 倍程度過大評価することが 示された。 